\title{
Recombinant Human Insulin-like Growth Factor-I Accelerates Recovery and Reduces Catabolism in Rats with Ischemic Acute Renal Failure
}

\author{
Hu Ding, Joel D. Kopple, Arthur Cohen, ${ }^{\star}$ and Raimund Hirschberg \\ Division of Nephrology and Hypertension, Harbor-UCLA Medical Center, Torrance, California 90509; and *Department of Pathology, \\ Cedars-Sinai Medical Center, and UCLA School of Medicine, Los Angeles, California 90048
}

\begin{abstract}
This study evaluated whether recombinant human insulin-like growth factor-I (rhIGF-I) enhances recovery of renal function and reduces catabolism in rats with ischemic acute renal failure (ARF). ARF and sham rats received subcutaneous injections of either rhIGF-I or vehicle three times daily starting $\mathbf{5} \mathbf{h}$ after surgery. Serum creatinine and urea, which initially rose similarly in the ARF + vehicle and ARF + rhIGF-I rats, increased more slowly after commencing the rhIGF-I injections. $72 \mathrm{~h}$ after surgery, the ARF + rhIGF-I rats, in comparison with ARF + vehicle animals, showed significantly greater renal plasma flow and filtration fraction, a fivefold higher glomerular filtration rate, greater renal cortical IGF-I levels, increased proliferating cell nuclear antigen expression in proximal tubule nuclei and enhanced DNA synthesis in the renal cortex, corticomedullary junction, glomeruli, and tubules as demonstrated by $\left[{ }^{3} \mathrm{H}\right]$ thymidine incorporation and in corticomedullary junction tubules as determined by autoradiography. Estimated total nitrogen output (ETNO) was greater in ARF + vehicle than in ARF + rhIGF-I or sham rats throughout the study. ETNO in ARF + rhIGF-I rats returned to sham values by the second day after surgery. $72 \mathrm{~h}$ after surgery, protein degradation was increased and protein synthesis reduced in the epitrochlearis muscle of ARF + vehicle as compared with ARF + rhIGF-I or sham + vehicle rats. Thus, treatment with rhIGF-I starting $5 \mathrm{~h}$ after inducing ischemic ARF in rats increases recovery of renal function, enhances formation of new renal tubular cells, lowers protein degradation, and increases protein synthesis in skeletal muscle and reduces net catabolism. (J. Clin. Invest. 1993. 91:2281-2287.) Key words: acute renal failure • glomerular filtration rate $\bullet$ insulin-like growth factor-I $\bullet$ mitosis $\bullet$ muscle protein metabolism
\end{abstract}

\section{Introduction}

Insulin-like growth factor-I (IGF-I) is a peptide growth factor that promotes hypertrophy and mitosis and stimulates protein

Address reprint requests to Dr. Raimund Hirschberg, Division of Nephrology and Hypertension, Harbor-UCLA Medical Center, 1000 West Carson Street, Torrance, CA 90509.

Received for publication 24 August 1992 and in revised form 10 February 1993.

J. Clin. Invest.

(c) The American Society for Clinical Investigation, Inc.

$0021-9738 / 93 / 05 / 2281 / 07 \$ 2.00$

Volume 91, May 1993, 2281-2287 synthesis and other anabolic processes $(1,2)$. In the normal rat or rabbit kidney, IGF-I is synthesized in the glomerulus and collecting ducts (3). Specific IGF-I receptors have been identified in glomeruli and proximal tubules (4). In normal rats, recombinant human IGF-I (rhIGF-I) ${ }^{1}$ causes renal hypertrophy and in both normal rats and humans, rhIGF-I acutely increases renal plasma flow (RPF) and glomerular filtration rate (GFR) (5-7).

Acute renal failure (ARF) results not only in the accumulation of potentially toxic metabolites but also is associated with increased degradation and reduced synthesis of protein $(8,9)$. Because rhIGF-I in normal animals is known to increase RPF and $\operatorname{GFR}(5,6)$, stimulate renal hypertrophy, and promote anabolism $(1,2)$, it is possible that rhIGF-I might have a specific role both in enhancing the recovery of renal function and also reducing the catabolic response to ARF. The following study was carried out to test the hypotheses that in rats with ischemic ARF: ( $a$ ) administration of rhIGF-I will enhance the rate of recovery of renal function, $(b)$ this recovery will be associated with an acceleration of nephron regeneration, and (c) rhIGF-I will also reduce the catabolic rate in these rats.

\section{Methods}

Male Sprague Dawley ( $n=14 ; 200-250 \mathrm{~g}$ body wt) rats (Charles River Breeding Laboratories, Boston, MA) with ischemic ARF and shamoperated $(n=14)$ rats were studied. Animals were anesthetized with an intramuscular injection of ketamine $(87 \mathrm{mg} / \mathrm{kg}$ body $\mathrm{wt})$ and xylazine ( $13 \mathrm{mg} / \mathrm{kg}$ body wt), and both kidneys were accessed through bilateral flank incisions. To cause ARF, both renal pedicles were clamped with baby Dieffenbach clamps for exactly $60 \mathrm{~min}$. Sham rats underwent a similar procedure without clamping the renal pedicles. The wounds were closed with sutures and skin clips. Throughout anesthesia, the body temperature was maintained with a heating pad. Rats were kept in individual metabolic cages during the $72 \mathrm{~h}$ immediately after the surgery. Animals were not given any food but had free access to water containing 5\% dextrose.

After surgery, the ARF and the sham rats were each randomly assigned to one of the following two treatment groups: (a) Seven ARF and seven sham rats received subcutaneous injections of rhIGF-I (Ciba-Geigy Corp., Summit, NJ), $50 \mu \mathrm{g} / 100 \mathrm{~g}$ body wt three times per day at 0800,1300 , and $2000 \mathrm{~h}$ (ARF + rhIGF-I, sham + rhIGF-I). Injections were begun at $5 \mathrm{~h}$ after induction of ARF. (b) Two other groups of ARF and sham rats ( $n=7$ for each group) received equal

1. Abbreviations used in this paper: ARF, acute renal failure; ETNO, estimated total nitrogen output; LpA, glomerular permeability coefficient; PAH, paraaminohippurate; PCNA, proliferating cell nuclear an-. tigen; rhIGF-I, recombinant human insulin-like growth factor-I; RPF, renal plasma flow; SUN, serum urea nitrogen. 
volumes of vehicle injections (i.e., normal saline) instead of rhIGF-I also at the same times (ARF + vehicle, sham + vehicle). Before surgery (baseline) and at 5, 24, 48, and $72 \mathrm{~h}$ after induction of ARF or sham surgery, $\sim 150 \mu$ l of tail blood was obtained to measure the serum concentrations of IGF-I, creatinine, and urea nitrogen (SUN). Urine was collected for each of the three 24-h periods after surgery to measure nitrogen excretion.

At $72 \mathrm{~h}$ after surgery, GFR was measured as the clearance of $\left[{ }^{3} \mathrm{H}\right]-$ inulin and RPF was calculated from the $\left[{ }^{14} \mathrm{C}\right]$ paraaminohippurate $(\mathrm{PAH})$ clearance and the renal extraction of $\mathrm{PAH}\left(E_{\mathrm{PAH}}\right)$ as previously described (5). After the clearance studies, both kidneys were removed. Approximately $200 \mathrm{mg}$ of renal cortex and of liver was obtained for extraction and measurement of IGF-I.

A coronal midsection of the kidney was obtained, placed in alcoholic Bouin's solution, embedded in paraffin, and cut; slides were stained with the periodic acid-Schiff method for histologic evaluation. Proliferating cell nuclear antigen (PCNA) expression was evaluated as previously described (10). Kidney sections were mounted on poly-Llysine-coated slides and incubated for $15 \mathrm{~min}$ with $3 \%$ methanolic peroxide to consume endogenous peroxidase. Sections were incubated with a monoclonal antibody to PCNA (PC-10 clone, DAKO Corp., Carpenteria, CA ) at 1:500 dilution for $30 \mathrm{~min}$, followed sequentially by a universal biotinylated anti-immunoglobulin for $30 \mathrm{~min}$ and streptavidin peroxidase for 30 min (both reagents from Lipshaw Immunon, Pittsburgh, PA). Antibody localization was performed using the peroxidase reaction with 3,3'-diaminobenzidine tetrahydrochloride (Aldrich Chemical Co., Milwaukee, WI). Slides were counterstained with hematoxylin and mounted with permount. A negative control slide for each animal was incubated with non-cross-reacting monoclonal antibody to factor VIII; it stained negative in all nuclei but positive in endothelial cell cytoplasm, thereby confirming tissue immunoreactivity. The slides were scored in a blinded fashion (by Dr. Cohen) using a semiquantitative scale from 0 (least PCNA staining) to 4 (greatest PCNA staining) for the frequency of positively stained nuclei. One slide containing a coronal section of a kidney from each rat was examined in its entirety. For the analysis, the outer two-thirds of the cortex and the corticomedullary junction were each completely surveyed and scored.

To further quantify the mitogenic effects of IGF-I on the kidney, 14 additional ARF rats were studied. Beginning $5 \mathrm{~h}$ after the induction of $\mathrm{ARF}$, rats received injections of rhIGF-I, $50 \mu \mathrm{g} / 100 \mathrm{~g}$ body wt $(n=8)$, or vehicle $(n=6)$ at 0800,1300 , and 2000 daily for $3 \mathrm{~d}$. At $71 \mathrm{~h}$ after surgery, each animal received a single intraperitoneal injection of $\left[{ }^{3} \mathrm{H}\right]-$ thymidine, $250 \mu \mathrm{Ci}$ (ICN Biomedicals, Irvine, CA). $1 \mathrm{~h}$ later rats were anesthetized, and available blood was aspirated from the abdominal aorta. Both kidneys were quickly removed, a coronal section was obtained for autoradiography, and $\sim 200 \mathrm{mg}$ of cortex and $200 \mathrm{mg}$ of corticomedullary junction tissue were obtained by dissection. In the remaining cortical tissue, glomeruli and tubules were separated by sieving (11). Total DNA was extracted from each sample, and the DNA concentration was measured with a fluorescence assay as previously described (12). The thymidine content was measured by scintillation counting (model LS-333, Beckman Instruments, Inc., Fullerton, CA). To ascertain that all animals had similar rates of thymidine absorption from the peritoneal cavity, the radioactivity of aortic serum was also counted. Autoradiography of the rat kidney tissue was performed as previously described (13).

To examine whether any anabolic effect of rhIGF-I could be associated with increased synthesis and/or reduced degradation of muscle protein, a separate study was carried out in ARF + rhIGF-I rats $(n$ $=9), \mathrm{ARF}+$ vehicle animals $(n=8)$ and sham + vehicle controls $(n$ $=6$ ). Fasting rats received injections of rhIGF-I or vehicle for $72 \mathrm{~h}$ after surgery at the same dosages and times as described above. At $72 \mathrm{~h}$ after surgery, the animals were anesthetized with ketamine and xylazine, and the epitrochlearis muscles were removed, placed in KRB ( $\mathrm{pH} 7.4$ containing chloramphenical $0.3 \mathrm{mg} /$ liter), and constantly gassed with $95 \% \mathrm{O}_{2} / 5 \% \mathrm{CO}_{2}$. Muscle protein synthesis and degradation were measured as previously described $(9,14,15)$. Briefly, the epitrochlearis muscle was preincubated in a shaking water bath at $37^{\circ} \mathrm{C}$ with $\mathrm{KRB}$, $\mathrm{pH} 7.4$, containing $10 \mathrm{mM}$ glucose, $0.1 \mathrm{mM}$ tyrosine, $0.5 \mu \mathrm{Ci}\left[{ }^{14} \mathrm{C}\right]-$ tyrosine, and gassed with $95 \% \mathrm{O}_{2} / 5 \% \mathrm{CO}_{2}$. After 30 min the muscle was removed, blotted, and reincubated for $2 \mathrm{~h}$ in a separate flask with the same media and gassing. The muscle was then removed, homogenized in cold $10 \%$ TCA, and centrifuged. Proteins in the medium were also precipitated with $6 \%$ TCA. The pellet from the homogenized, precipitated muscle and the pellet from the medium were each washed with $6 \% \mathrm{TCA}$ and then dissolved in $0.2 \mathrm{~N} \mathrm{NaOH}$. The radioactivity of the two redissolved pellets as well as of the supernatant from the medium was measured with a scintillation counter (model LS-333, Beckman Instruments, Inc.). Total tyrosine in the supernatant from the medium was measured fluorometrically as described by Waalkes and Udenfriend (16). Protein synthesis was calculated by dividing the radioactivity in muscle protein during the 2 - $\mathrm{h}$ incubation period by the specific activity of tyrosine in the medium.

The method for measuring protein degradation was the same as for protein synthesis except that $0.5 \mathrm{mM}$ of the protein synthesis inhibitor cycloheximide was added, and neither labeled nor unlabeled tyrosine was included in the incubation media. After $2 \mathrm{~h}$ of incubation, the media was deproteinized with TCA, and the tyrosine content of the deproteinized medium was measured. Protein degradation was calculated from the rate of release of total tyrosine into the media during the 2-h incubation. Both protein synthesis and degradation are expressed as nanomoles tyrosine per gram muscle weight per hour.

IGF-I was extracted from renal cortex, liver, and serum before measurement by RIA. Renal cortex and liver were homogenized in $1.0 \mathrm{M}$ acetic acid and extracted twice with acid ethanol. Serum was acidified with $0.5 \mathrm{M} \mathrm{HCl}$ for $2 \mathrm{~h}$ at room temperature and separated from the binding proteins with HPLC on an acetonitrile gradient in $0.1 \%$ trifluoroacetic acid using a C-18 peptide column (VYDAK, Hisperia, CA). IGF-I was measured by specific RIA as previously described (6). Serum creatinine and SUN were measured by routine laboratory methods. Estimated total nitrogen output (ETNO) was calculated as the sum of the urinary urea nitrogen and ammonium nitrogen and the change in body urea nitrogen, which was determined as previously described (8). Urine urea and ammonium were measured with the A-Gent BUN kit (Abbott Laboratories, South Pasadena, CA).

Statistical significance was generally determined by analysis of variance and the Newman-Keuls multiple comparison test. Exceptions were the thymidine incorporation measurements which were compared by the $t$ test and the PCNA expression which was examined by the Mann-Whitney $U$ test. Statistical significance was defined as $\mathbf{P}$ $<0.05$. Variance is expressed as standard error of the mean or range of values.

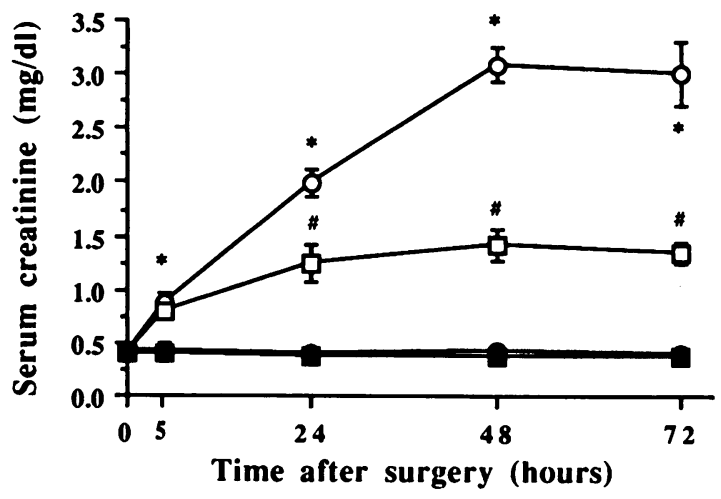

Figure 1. Serum creatinine before $(0 \mathrm{~h})$ and after induction of ischemic ARF or sham surgery. Treatment with rhIGF-I or vehicle was begun after the measurement at $5 \mathrm{~h}$ was obtained. (O) ARF + vehicle;

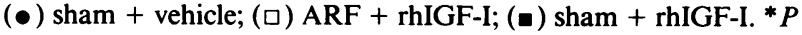
$<0.05$ vs. sham + rhIGF-I or sham + vehicle; $" P<0.05$ vs. ARF + vehicle. 


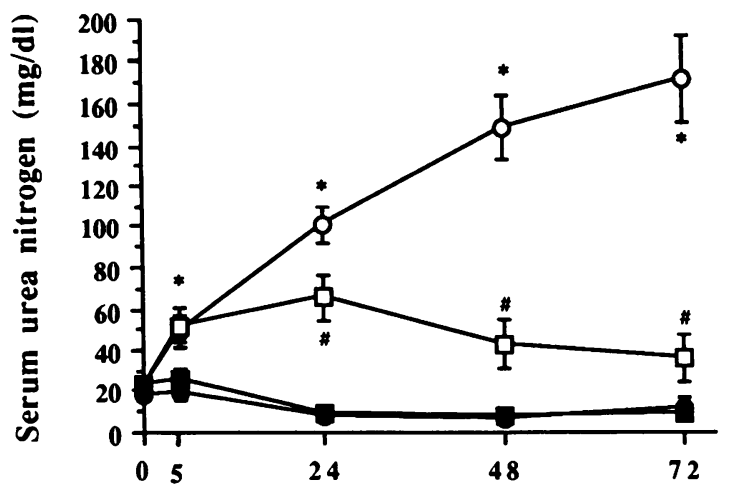

Time after surgery (hours)

Figure 2. Serum urea nitrogen levels before $(0 \mathrm{~h})$ and after induction of ischemic ARF or sham surgery. Treatment with rhIGF-I was begun after the measurement at $5 \mathrm{~h}$ was obtained. (O) ARF + vehicle; $(\bullet)$ sham + vehicle; ( $\square$ ) ARF + rhIGF-I; $(\square)$ sham + rhIGF-I. ${ }^{*} P<0.05$ vs. sham + rhIGF-I or sham + vehicle; ${ }^{*} P<0.05$ vs. ARF + vehicle.

\section{Results}

During the initial $5 \mathrm{~h}$ after surgery, serum creatinine and SUN rose similarly in the two groups of ARF rats but did not change in the sham animals (Figs. 1 and 2). In the ARF + vehicle rats, the serum creatinine and urea continued to rise steeply. The peak serum creatinine, which occurred $48 \mathrm{~h}$ after surgery, was $3.09 \pm 0.06 \mathrm{mg} / \mathrm{dl}$, and the maximum SUN was $172 \pm 16 \mathrm{mg} / \mathrm{dl}$. In contrast, ARF + rhIGF-I rats displayed a lesser rate of increase in serum creatinine and urea; in this latter group of animals the maximum serum creatinine, which also occurred at $48 \mathrm{~h}$, was $1.41 \pm 0.06 \mathrm{mg} / \mathrm{dl}$, and the peak SUN was $65 \pm 4$ $\mathrm{mg} / \mathrm{dl}$. The slope of the SUN curves in these two groups of rats was even more different, continuing to rise throughout the $72 \mathrm{~h}$ in the ARF + vehicle rats and falling progressively after $24 \mathrm{~h}$ in the ARF + rhIGF-I animals (Fig. 2). The serum creatinine and SUN levels were each significantly greater in the ARF + vehicle animals as compared with the ARF + rhIGF-I, sham + vehicle, or sham + rhIGF-I rats at 24,48 , and $72 \mathrm{~h}$ after surgery. In the $\mathrm{ARF}+$ rhIGF-I rats, the serum creatinine and SUN values were also significantly greater at each point after surgery in comparison with the two groups of sham animals. There were

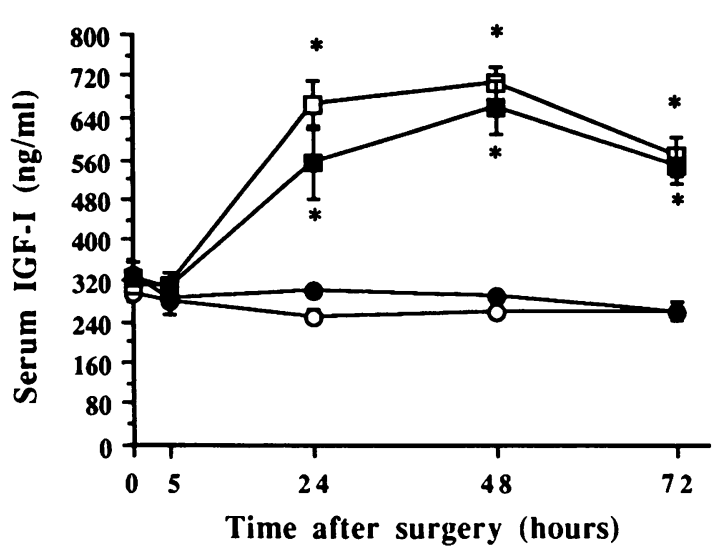

Figure 3. Serum IGF-I levels before $(0 \mathrm{~h})$ and after induction of ischemic ARF or sham surgery. Treatment with rhIGF-I was begun after the measurement at $5 \mathrm{~h}$ was obtained. ( 0 ) ARF + vehicle; $(\bullet)$ sham + vehicle; ( $\square)$ ARF + rhIGF-I; (घ) sham + rhIGF-I. ${ }^{*} P<0.05$ vs. sham + vehicle or ARF + vehicle.

no differences in either the serum creatinine or SUN after surgery between the two groups of sham rats.

The ARF + vehicle rats demonstrated a marked reduction in RPF and GFR as compared with the sham + vehicle animals (Table I). The ARF rats treated with rhIGF-I displayed a GFR that was approximately fivefold greater than in the ARF + vehicle rats $(P<0.05$, Table $\mathrm{I})$. RPF was also increased in the ARF + rhIGF-I rats as compared with the ARF + vehicle animals $(P<0.05)$ but to a more modest degree. Thus, the ARF + rhIGF-I rats displayed a higher filtration fraction than the ARF + vehicle animals $(P<0.05)$. Despite this improvement in renal function, the RPF, GFR, and filtration fraction in ARF + rhIGF-I rats were still significantly lower than in sham + vehicle animals. Consistent with our previous findings in normal rats receiving rhIGF-I $(5,6)$, the sham + rhIGF-I rats showed a higher RPF and GFR than the sham + vehicle animals (Table I). ARF resulted in a severe reduction in $E_{\mathrm{PAH}}$ as compared with the sham-operated controls (Table I). The $E_{\mathrm{PAH}}$ was decreased most markedly in the ARF + vehicle rats. The renal extraction of PAH was greater in the ARF + rhIGF-I rats, but was still significantly lower than in the sham + vehicle rats. The $E_{\mathrm{PAH}}$ was not different in the sham + rhIGF-I rats as compared with the sham + vehicle controls.

Table I. Renal Hemodynamics in ARF and Sham-operated Rats at $72 \mathrm{~h}$ after Induction of ARF

\begin{tabular}{|c|c|c|c|c|c|}
\hline & GFR & RPF & RBF & Filtration fraction & $E_{\mathrm{PAH}}$ \\
\hline \multicolumn{6}{|c|}{$\mu \mathrm{g} / \mathrm{min}$ per $100 \mathrm{~g}$ body $w t$} \\
\hline ARF + vehicle & $\begin{array}{l}34 \pm 6 \\
(17-59)\end{array}$ & $835 \pm 92$ & $1544 \pm 182$ & $0.041 \pm 0.006$ & $0.066 \pm 0.009$ \\
\hline ARF + rhIGF-I & $\begin{array}{l}165 \pm 20^{* \pm} \\
(102-227)\end{array}$ & $1150 \pm 73^{* \pm}$ & $2131 \pm 108^{* \ddagger}$ & $0.150 \pm 0.025^{* \ddagger}$ & $0.262 \pm 0.048^{*}$ \\
\hline Sham + vehicle & $\begin{array}{l}613 \pm 22^{*} \\
(506-664)\end{array}$ & $2504 \pm 97^{*}$ & $5060 \pm 192^{*}$ & $0.239 \pm 0.007^{*}$ & $0.785 \pm 0.089^{*}$ \\
\hline Sham + rhIGF-I & $\begin{array}{l}722 \pm 25^{* \neq} \\
(641-854)\end{array}$ & $3059 \pm 68^{* \pm}$ & $5894 \pm 122^{* \pm}$ & $0.269 \pm 0.030^{*}$ & $0.780 \pm 0.026^{*}$ \\
\hline
\end{tabular}

Values are mean $\pm \mathrm{SEM} ; n=7$ per group; ${ }^{*} P<0.05$ vs. ARF + vehicle; ${ }^{\ddagger} P<0.05$ vs. sham + vehicle; numbers in parentheses indicate range of values. 
Table II. Serum, Liver, and Renal Cortex IGF-I Concentrations at 72 h after Bilateral Clamping of Renal Pedicles or Sham Surgery

\begin{tabular}{lccc}
\hline & Serum IGF-I & Liver IGF-I & Renal cortical IGF-I \\
\hline & $n g / m l$ & \multicolumn{2}{c}{$p g / m g$ protein } \\
ARF + vehicle & $260 \pm 19$ & $78 \pm 9$ & $50 \pm 6$ \\
ARF + rhIGF-I & $566 \pm 39^{\ddagger}$ & $64 \pm 9$ & $70 \pm 5^{* \ddagger}$ \\
Sham + vehicle & $258 \pm 7$ & $87 \pm 14$ & $122 \pm 14^{*}$ \\
Sham + rhIGF-I & $548 \pm 36^{\ddagger}$ & $83 \pm 7$ & $88 \pm 15^{*}$ \\
& & & \\
\hline
\end{tabular}

Values are means \pm SEM; $n=7$ rats per group; ${ }^{*} P<0.05$ vs. ARF + vehicle; ${ }^{\ddagger} P<0.05$ vs. sham + vehicle.

Serum IGF-I levels did not change significantly in the ARF and sham animals that did not receive rhIGF-I (Fig. 3). In both the ARF and sham rats treated with rhIGF-I, the serum levels rose to about twice baseline (Fig. 3). The liver IGF-I levels at $72 \mathrm{~h}$ after surgery were similar in all four groups of rats (Table II). The mean renal cortical IGF-I levels at $72 \mathrm{~h}$ in the ARF + vehicle and ARF + rhIGF-I rats were both reduced to $41 \%$ and $57 \%$ of the values of the sham + vehicle animals, respectively $(P<0.05$ for each group). However, the cortical IGF-I concentrations were also significantly lower in the ARF + vehicle rats as compared with the ARF + rhIGF-I rats. In contrast, the sham + rhIGF-I rats did not have increased cortical IGF-I levels as compared with the sham + vehicle animals.

The DNA synthesis measured as thymidine incorporation into DNA was significantly greater in the ARF + rhIGF-I rats as compared with the ARF + vehicle animals in each of the four tissue components measured (Table III). rhIGF-I treatment was associated with an increase in thymidine incorporation into DNA of about fourfold in the renal cortex, sevenfold in the corticomedullary junction, fivefold in the glomeruli, and sevenfold in separated tubular cells. Each of these measurements of thymidine incorporation was significantly greater $(P$ $<0.05$ ) in the ARF + rhIGF-I rats as compared with the ARF + vehicle animals. The serum thymidine levels were similar in both groups. Light microscopy showed severe proximal tubular necrosis in both groups of ARF rats. Tubular necrosis was most pronounced in the corticomedullary junction corresponding to the second and third proximal tubular segments. Nephrons in both sham-operated groups appeared to be normal. Counting of mitoses in proximal tubules in 50 consecutive high power fields showed a tendency, not significant, for more frequent mitoses in the ARF + rhIGF-I rats than in the ARF + vehicle animals. Autoradiography localized most of the radioactivity to the proximal tubule cells in the corticomedullary junction (Fig. 4). There was considerably more precipitation of silver chloride in the tubule cells from the ARF + rhIGF-I rats than the ARF + vehicle animals. In the ARF + vehicle rats and both groups of sham controls the glomeruli were autoradiographically negative. However, in ARF + rhIGF-I rats occasional glomeruli showed $\left[{ }^{3} \mathrm{H}\right]$ thymidine tracings in parietal epithelial cells.

The PCNA expression in proximal tubule cell nuclei is shown in Table IV. In the ARF + vehicle rats as compared with the sham + vehicle animals, there was significantly greater PCNA staining in the corticomedullary junction and in the outer two thirds of cortex; no differences were observed between the ARF + vehicle rats and the sham + rhIGF-I animals. The ARF + rhIGF-I rats displayed significantly greater proximal tubule PCNA staining in both the outer two thirds of the cortex and the corticomedullary junction as compared with the $\mathrm{ARF}+$ vehicle rats and the sham + vehicle animals. PCNA expression in distal tubule cell nuclei in these same kidney sections tended to show similar alterations as were observed for the proximal tubule cells in the ARF + vehicle and ARF + rhIGF-I rats.

The ETNO in the ARF + vehicle rats during the first $24 \mathrm{~h}$ after surgery was markedly increased as compared with the sham + vehicle and sham + rhIGF-I rats (Table V). The ETNO fell progressively during the next $2 \mathrm{~d}$ in the ARF + vehicle rats, but remained significantly greater than in the sham animals during each 24-h period. The ETNO in the ARF + rhIGF-I rats was also significantly greater than in the sham + vehicle or sham + rhIGF-I animals during the first $24 \mathrm{~h}$ after surgery. Subsequently, in the ARF + rhIGF-I rats, the ETNO fell rapidly to the sham control levels (Table V). The ETNO was significantly lower in the ARF + rhIGF-I rats as compared with the ARF + vehicle animals during each 24-h period of study. There was no difference in the ETNO between the sham + vehicle and sham + rhIGF-I rats during any given day after surgery.

Epitrochlearis muscle protein synthesis at $72 \mathrm{~h}$ after surgery was significantly reduced in the ARF + vehicle rats as compared to the sham + vehicle animals (Table VI). On the other hand, protein synthesis was significantly greater in the ARF rats given rhIGF-I as compared with both the ARF + vehicle rats and sham + vehicle animals. Muscle protein degradation was significantly greater in the ARF + vehicle rats as compared with the sham + vehicle animals ( Table VI). In contrast, protein degradation was significantly lower in the ARF + rhIGF-I

Table III. Thymidine Incorporation into DNA Extracted from Different Renal Tissues at $72 h$ after Induction of ARF

\begin{tabular}{|c|c|c|c|c|}
\hline & Cortex & Corticomedullary junction & Glomeruli & Tubules \\
\hline & & & & \\
\hline $\begin{array}{l}\mathrm{ARF}+\text { vehicle } \\
\quad(n=6)\end{array}$ & $6,375 \pm 1,992$ & $6,870 \pm 2,133$ & $692 \pm 180$ & $7,565 \pm 2,269$ \\
\hline $\begin{array}{l}\text { ARF + rhIGF-I } \\
\quad(n=8)\end{array}$ & $\begin{array}{c}26,354 \pm 3,396 \\
P<0.001\end{array}$ & $\begin{array}{c}51,115 \pm 9,466 \\
P<0.002\end{array}$ & $\begin{array}{c}3,203 \pm 679 \\
P<0.01\end{array}$ & $\begin{array}{c}50,015 \pm 10,898 \\
P<0.01\end{array}$ \\
\hline
\end{tabular}

Values are mean \pm SEM; Data are expressed as cpm of $\left[{ }^{3} \mathrm{H}\right]$ thymidine/mg DNA. Statistics were performed by the unpaired $t$ test. 

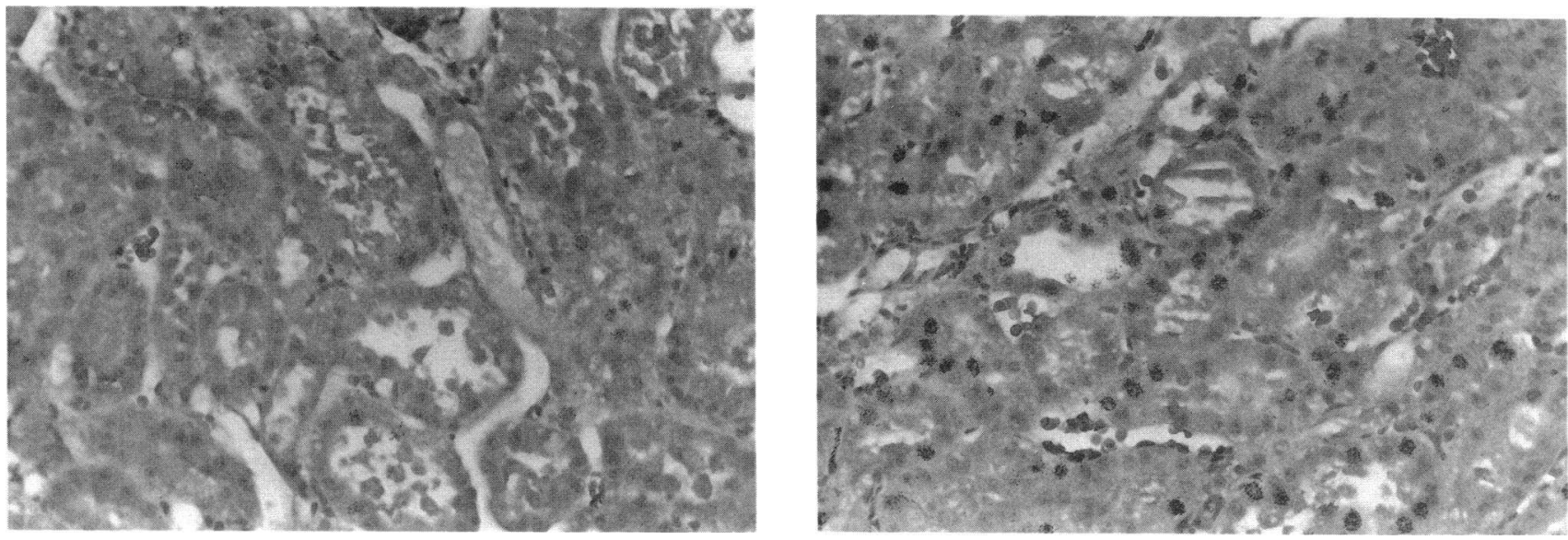

Figure 4. Representative renal autoradiographs from an ARF + vehicle animal (left) and an ARF + rhIGF-I rat (right); kidneys were removed 1 $\mathrm{h}$ after intraperitoneal injection of $250 \mu \mathrm{Ci}$ of $\left[{ }^{3} \mathrm{H}\right]$ thymidine. Autoradiographs were slightly counterstained with hematoxylin and eosin. $\times 400$.

treated rats as compared with either the $\mathrm{ARF}+$ vehicle rats or sham + vehicle animals.

\section{Discussion}

In this study we investigated whether treatment with rhIGF-I accelerates the recovery of renal function and reduces the catabolic rate in rats with experimental ischemic acute renal failure. The results clearly demonstrate that rhIGF-I improves renal function in these rats, as estimated by the lower serum creatinine levels as well as by direct measurements of RPF and GFR at $72 \mathrm{~h}$ after surgery. Furthermore, rhIGF-I reduces the total nitrogen output in rats with ARF.

There are possibly two mechanisms by which rhIGF-I increased RPF and GFR. First, rhIGF-I probably had a direct hemodynamic effect on the kidney. The evidence for this is the fact that the serum creatinine rapidly responded to rhIGF-I treatment. The serum creatinine at $5 \mathrm{~h}$ after surgery was virtually identical in the two groups of ARF rats, indicating that the severity of renal injury and the degree of renal failure were similar in these two groups (Fig. 1). Yet, $19 \mathrm{~h}$ later the serum creatinine was significantly lower in the ARF + rhIGF-I rats as compared with the ARF + vehicle animals. This rapid response to rhIGF-I is suggestive of a hemodynamic action of this com-

Table IV. PCNA Expression in Proximal Tubule Cells at 72 h after Surgery

\begin{tabular}{lrcc}
\hline & $\begin{array}{c}\text { No. of } \\
\text { rats }\end{array}$ & $\begin{array}{c}\text { Outer two thirds } \\
\text { of cortex }\end{array}$ & $\begin{array}{c}\text { Corticomedullary } \\
\text { junction }\end{array}$ \\
\hline ARF + vehicle & 7 & $1.25(1.0-1.5)$ & $2.8(2.25-3.25)$ \\
ARF + rhIGF-I & 10 & $2.4(1.5-3.5)^{* \ddagger}$ & $4.0(3.25-4.0)^{* \ddagger}$ \\
Sham + vehicle & 4 & $0.25(0-1.0)^{*}$ & $1.4(1.0-2.5)^{*}$ \\
Sham + rhIGF-I & 5 & $0.75(0-1.0)^{*}$ & $2.5(2.0-4.0)^{\ddagger}$ \\
\hline
\end{tabular}

Scores (0-4) were blindly assigned and averaged for two sections in each rat. Values are given as the median and range. Statistics were performed by Mann-Whitney $U$ test; ${ }^{*} P<0.05$ vs. ARF + vehicle; ${ }^{\ddagger} P<0.05$ vs. sham + vehicle. pound and is consistent with our previous findings in normal rats that rhIGF-I rapidly increases RPF and GFR (5). This increase in renal hemodynamics in normal rats appears to be due to a reduction in afferent renal arteriolar resistance, a rise in the glomerular permeability coefficient ( LpA) and possibly to a reduction in efferent renal arteriolar resistance (6). The finding that the filtration fraction did not change in the normal rats given rhIGF-I $(5,6)$ but increased more than threefold in the ARF rats (Table I) indicates that the mechanism of action of rhIGF-I in rats with ischemic ARF may be somewhat different, probably by exerting its predominant effect of LpA.

Second, other evidence suggests that rhIGF-I may accelerate healing from acute ischemic nephron injury by its mitogenic actions. There was significantly greater DNA synthesis in the renal cortex, corticomedullary junction, isolated glomeruli, and tubules of the ARF + rhIGF-I as compared to the ARF + vehicle rats as indicated by $\left[{ }^{3} \mathrm{H}\right]$ thymidine uptake (Table III). Autoradiography demonstrated that the radioactivity was largely localized to the proximal tubule cells in the corticomedullary junction. Also, PCNA expression, although increased in the outer two thirds of the cortex and the corticomedullary junction in the ARF + vehicle rats as compared with the sham + vehicle animals, was greater in the ARF + rhIGF-I rats than in either of these other two groups of animals (Table IV). PCNA is a $36-k D$ DNA polymerase-delta protein that is in-

Table V. ETNO in the Rats during the Three 24-h Periods after ARF or Sham Surgery

\begin{tabular}{lrcc}
\hline & $0-24 \mathrm{~h}$ & $25-48 \mathrm{~h}$ & $49-72 \mathrm{~h}$ \\
\hline & & $m g N / 24 \mathrm{~h}$ & \\
ARF + vehicle & $157 \pm 14^{\ddagger}$ & $71 \pm 9^{\ddagger}$ & $40 \pm 14^{\ddagger}$ \\
ARF + rhIGF-I & $99 \pm 6^{* \ddagger}$ & $12 \pm 1^{*}$ & $24 \pm 2^{*}$ \\
Sham + vehicle & $3 \pm 1^{*}$ & $14 \pm 2^{*}$ & $20 \pm 2^{*}$ \\
Sham + rhIGF-I & $3 \pm 1^{*}$ & $20 \pm 3^{*}$ & $27 \pm 2$ \\
& & & \\
\hline
\end{tabular}

Values are means \pm SEM; $n=7$ rats per group. ${ }^{*}$ Differs from ARF + vehicle, $P<0.05$. ${ }^{\ddagger}$ Differs from sham + vehicle, $P<0.05$.

Statistics by ANOVA and Newman-Keuls test. 
Table VI. Epitrochlearis Muscle Protein Synthesis and Degradation Rates at $72 \mathrm{~h}$ after Surgery

\begin{tabular}{|c|c|c|c|}
\hline & $\begin{array}{c}\mathrm{ARF}+\text { vehicle } \\
\quad(n=8)\end{array}$ & $\begin{array}{c}\text { ARF + rhIGF-I } \\
(n=9)\end{array}$ & $\begin{array}{c}\text { Sham }+ \text { vehicle } \\
(n=6)\end{array}$ \\
\hline $\begin{array}{l}\text { Muscle protein synthesis } \\
\quad(\text { nmol Tyr/g per } h)\end{array}$ & $31.5 \pm 2.6$ & $47.8 \pm 3.8^{* \ddagger}$ & $41.8 \pm 5.6^{*}$ \\
\hline $\begin{array}{c}\text { Muscle protein } \\
\text { degradation }\end{array}$ & & & \\
\hline$($ nmol Tyr/g per $h)$ & $217 \pm 15.9$ & $143 \pm 10.2^{* \pm}$ & $189 \pm 26^{*}$ \\
\hline
\end{tabular}

Values are mean $\pm \mathrm{SEM} ;{ }^{*} P<0.01$ vs. ARF + vehicle; ${ }^{\ddagger} P<0.01$ vs. sham + vehicle. Tyr, tyrosine.

creased in nuclei before DNA replication. PCNA is detectable throughout the G1, S, and G2 phases of the cell cycle and is a sensitive index of cell proliferation. It has been used primarily as a marker of the proliferative activity of various tumors and also of other cells (17-19). The finding of increased PCNA in the proximal tubules of the ARF + vehicle rats as compared with the sham + vehicle animals is consistent with increased cell mitosis known to occur in the kidney of rats recovering from acute ARF.

IGF-I has been previously shown to promote mitogenesis in tubular epithelial cells (20). To the authors' knowledge, this is the first report that IGF-I stimulates mitogenesis in the mature kidney. Because rhIGF-I was not administered until $5 \mathrm{~h}$ after the reestablishment of blood flow in the ischemic kidney, it is unlikely that rhIGF-I protected the ischemic kidney against injury. Rather, it most probably accelerated recovery by the two mechanisms described above.

The disproportionately greater reduction in the GFR as compared to the RPF (i.e., low filtration fraction) and the very low $E_{\mathrm{PAH}}$ in the ARF + vehicle rats at $72 \mathrm{~h}$ after surgery (Table I) are similar to previous findings in rats with ischemia induced ARF (21). These results were previously attributed to a severe reduction in LpA secondary to ischemic glomerular injury (22). It is of interest that treatment with rhIGF-I caused a disproportionate increase in GFR, to $485 \%$ of the vehicle treated ARF rats, as compared with the rise in the RPF to only $128 \%$ of values in the ARF rats given vehicle. In the ARF + rhIGF-I rats as compared to the ARF + vehicle animals, the $E_{\mathrm{PAH}}$ rose greater than the increase in GFR (Table I). This indicates that tubular secretion of PAH also rose with rhIGF-I treatment. Thus, the contribution of the tubule to the renal extraction of PAH (calculated as the $E_{\mathrm{PAH}}$ minus the filtration fraction ) in the ARF + vehicle, ARF + rhIGF-I, sham + vehicle, and sham + rhIGF-I rats averaged $0.025,0.112,0.546$, and 0.511 , respectively. These findings suggest that rhIGF-I also enhanced tubular extraction of PAH, although not to normal or control values. Because PAH is primarily secreted by the proximal tubules (23), these findings provide evidence that rhIGF-I enhanced recovery of proximal tubule cell function as well as GFR and RPF.

Several reports suggest that growth factors may play a role in the kidney repair from ischemic or toxic ARF (13, 24-26). In ARF, there is initially a decrease in pre-pro EGF $m$ RNA and the urinary excretion of EGF also falls (13). Administration of exogenous EGF, a potent mitogen for renal tubular cells, ap- pears to enhance proximal tubular cell mitosis and recovery of renal function in rats with ARF (24-26).

In the kidney of normal adult animals, IGF-I appears to be produced in the collecting duct but not in proximal tubule cells $(3,27)$. However, IGF-I and IGF-I mRNA have been identified by immunohistochemistry and in situ hybridization in the proximal tubule cells of rats recovering from $\operatorname{ARF}(28,29)$. These findings are consistent with the possibility that IGF-I plays a role in tubular cell repair after acute injury. It is pertinent that the renal cortical IGF-I concentrations were reduced in the ARF rats given vehicle, and these values were increased, although not to normal levels, in the ARF rats receiving rhIGFI ( Table II).

Net protein breakdown appeared to be similar in the ARF + rhIGF-I and the ARF + vehicle rats during the first $5 \mathrm{~h}$ after surgery, before rhIGF-I treatment was inaugurated. This inference is based on the finding that the SUN and the SUN/serum creatinine ratio at 0 and $5 \mathrm{~h}$ were similar in these two groups of rats. However, during the first $24 \mathrm{~h}$ after surgery, the ETNO was significantly lower in the ARF + rhIGF-I rats than in the ARF + vehicle animals ( Table V). Moreover, after the first 24 $h$, the ETNO was no different in the ARF + rhIGF-I animals as compared with the two groups of sham rats, whereas it remained elevated in the ARF + vehicle rats. These findings indicate that rhIGF-I dramatically reduced the net catabolic rate in the ARF rats. The estimated nitrogen output was rather low in the groups of sham-operated rats. This may reflect the fact that the rats were given $5 \%$ dextrose in the drinking water because of concern that rhIGF-I might cause hypoglycemia in these fasted animals. The amount of calories derived from the D-glucose in the drinking water may have reduced the net protein catabolism in these rats.

The finding that muscle protein degradation was increased and synthesis decreased in the ARF + vehicle rats as compared with the sham + vehicle animals is consistent with the higher negative nitrogen balance in the former animals, as indicated by their greater ETNO (Table V). These results also support previous findings that ARF in rats is associated with enhanced degradation and reduced synthesis of skeletal muscle protein $(8,9)$. The observation that muscle protein degradation was lower and synthesis greater in the ARF + rhIGF-I rats as compared with ARF + vehicle rats also is consistent with the lower ETNO and, hence, less negative nitrogen balance in the ARF + rhIGF-I rats. This anabolic effect of rhIGF-I might be due, in part, to an improved metabolic milieu secondary to the improved renal function in the ARF + rhIGF-I rats. However, it is unlikely that such improvement in renal function accounts for all of the anabolic effects of rhIGF-I. The finding that muscle protein degradation was decreased and muscle protein synthesis was greater in the ARF + rhIGF-I rats as compared with the sham + vehicle rats, even though the RPF and GFR were lower in the former animals, suggests that rhIGF-I probably exerted anabolic effects on skeletal muscle that were independent of its actions on renal function.

The findings of this study are potentially of substantial significance, because ARF is frequently associated with reduced protein synthesis and, increased protein degradation in skeletal muscle and elevated nitrogen losses $(8,9,30)$. In humans with ARF, the net catabolic rate can be markedly elevated (30). Thus, an agent that both enhances recovery of renal function and reduces the net catabolic rate may be particularly useful in 
the management of ARF. Another unique feature of this study was that rhIGF-I enhanced the recovery of renal function and reduced the net catabolic rate even though it was not administered until $5 \mathrm{~h}$ after surgery. Thus, rhIGF-I might be of particular value because it may exert its effects even when administered after ARF is established.

\section{Acknowledgments}

The recombinant human IGF-I was kindly provided by Dr. Hans-Peter Guler, Ciba-Geigy Corp., Summit, NJ.

This study was supported by grant-in-aid no. 901218 from the American Heart Association to Dr. Hirschberg.

\section{References}

1. Tomas, F., S. Knowles, P. Owens, L. Read, C. Chandler, S. Gargosky, and F. Ballard. 1991. Effects of full-length and truncated insulin-like growth factoron nitrogen balance and muscle protein metabolism in nitrogen-restricted rats. $J$. Endocrinol. 128:97-105.

2. Conti, G., L. Striker, M. Lesniak, K. MacKay, J. Roth, and G. Striker 1988. Studies on binding and mitogenic effect of insulin and insulin-like growth factor I in glomerular mesangial cells. Endocrinology. 122:2788-2795.

3. Bortz, J., P. Rotwein, D. DeVol, P. Bechtel, V. Hansen, and M. Hammerman. 1988. Focal expression of insulin-like growth factor I in rat kidney collecting duct. J. Cell Biol. 107:811-819.

4. Pillion, D., J. Haskell, and E. Meezan. 1988. Distinct receptors for insulinlike growth factor I in rat renal glomeruli and tubules. Am. J. Physiol. (Endocrinol. Metab. 18) 255:E504-E512.

5. Hirschberg, R., and J. Kopple. 1989. Evidence that insulin-like growth factor I increases renal plasma flow and glomerular filtration rate in fasted rats. $J$. Clin. Invest. 83:326-330.

6. Hirschberg, R., J. Kopple, R. Blantz, and B. Tucker. 1991. Effects of recombinant human insulin-like growth factor I on glomerular dynamics in the rat. $J$. Clin. Invest. 87:1200-1206.

7. Hirschberg, R., G. Brunori, J. Kopple, and H. P. Guler. 1993. Effects of insulin-like growth factor I on renal function in normal men. Kidney Int. 43:387397.

8. Flügel-Link, R., I. Salusky, M. Jones, and J. Kopple. 1983. Protein and amino acid metabolism in posterior hemicorpus of acutely uremic rats. Am. J. Physiol. (Endocrinol. Metab. 7) 244:E615-E623.

9. Clark, A. S., and W. E. Mitch. 1983. Muscle protein turnover and glucose uptake in acutely uremic rats. J. Clin. Invest. 72:836-845.

10. Said, J. W., G. S. Pinkus, M. A. Jones, M. Preston, and P. Shintaku. 1993 Expression of bcl-2 oncogene protein in malignant lymphomas, including Hodgkin's disease and non-Hodgkin's lymphomas of the T-cell phenotype. Appl. Im munohistochem. In press.

11. Hirschberg, R., and J. Kopple. 1991. Response of insulin-like growth factor I and renal hemodynamics to a high and low protein diet in the rat. J. Am Soc. Nephrol. 1:1034-1040.
12. Labarca, C., and K. Paigen. 1980. A simple, rapid and sensitive DNA assay procedure. Anal. Biochem. 102:344-352.

13. Safirstein, R., P. Price, S. Saggi, and R. Harris. 1990. Changes in gene expression after temporary renal ischemia. Kidney Int. 37:1515-1521.

14. May, R. C., R. A. Kelly, and W. E. Mitch. 1986. Metabolic acidosis stimulates protein degradation in rat muscle by a glucocorticoid-dependent mechanism. J. Clin. Invest. 77:614-621.

15. Clark, A. S., and W. E. Mitch. 1983. Comparison of protein synthesis and degradation in incubated and perfused muscle. Biochem. J. 212:649-653.

16. Waalkes, T. P., and S. A. Udenfriend. 1957. A method for the estimation of tyrosine in plasma and tissues. J. Lab. Clin. Med. 50:733-736.

17. Hall, P. A., D. A. Levison, A. L. Woods, C. C.-W. Yu, D. B. Kellock, J. A Watkins, D. M. Barnes, C. E. Gillett, R. Camplejohns, R. Dover, et al. 1990 Proliferating cell nuclear antigen (PCNA) immunolocalization in paraffin sections: an index of cell proliferation with evidence of deregulated expression in some neoplasms. J. Pathol. 162:285-294.

18. Theunissen, P. H. M. H., M. P. G. Leers, and E. C. M. Bollen. 1992 Proliferating cell nuclear antigen (PCNA) expression in formalin-fixed tissue of non-small cell lung carcinoma. Histopathology. 20:251-255.

19. Isik, F. F., M. Ferguson, E. Yamanaka, and D. Gordon. 1992. Proliferating cell nuclear antigen: A marker for cell proliferation in autopsy tissues. Arch. Pathol. Lab. Med. 116:1142-1146.

20. Zhang, G., T. Ichimura, A. Wallin, M. Kan, and J. Stevens. 1991. Regulation of rat proximal tubule epithelial cell growth by fibroblast growth factors, insulin-like growth factor- 1 and transforming growth factor- $\beta$, and analysis of fibroblast growth factors in rat kidney. J. Cell. Physiol. 148:295-305.

21. Arendshorst, W., W. Finn, and C. Gottschalk. 1975. Pathogenesis of acute renal failure following renal ischemia in the rat. Circ. Res. 37:558-568.

22. Williams, R., C. Thomas, L. Navar, and A. Evan. 1981. Hemodynamic and single nephron function during maintenance phase of ischemic acute renal failure in the dog. Kidney Int. 19:503-515.

23. Shimohura A., Chonko, A., Grantham, J. J. 1981. Basis of heterogenicity of paraaminohippurate secretion in rabbit proximal tubules. Am. J. Physiol. 240:F430-F436.

24. Humes, D., D. Cieslinski, T. Coimbra, J. Messana, and C. Galvao. 1989. Epidermal growth factor enhances renal tubule cell regeneration and repair and accelerates the recovery of renal function in postischemic acute renal failure. $J$. Clin. Invest. 84:1757-1761.

25. Coimbra, T., D. Cieslinski, and D. Humes. 1990. Epidermal growth factor accelerates renal repair in mercuric chloride nephrotoxicity. Am. J. Physiol. (Renal Fluid Electrolyte Physiol. 28) 259:F438-F443.

26. Norman, J., Y. Tsau, A. Bacay, and L. Fine. 1990. Epidermal growth factor accelerates functional recovery from ischaemic acute tubular necrosis in the rat: role of the epidermal growth factor receptor. Clin. Sci. (Lond.). 78:445450 .

27. Andersson, G., A. Skottner, and E. Jennische. 1988. Immunocytochemical and biochemical localization of insulin-like growth factor I in the kidney of rats before and after uninephrectomy. Acta Endocrinol. 119:555-560.

28. Andersson, G., and E. Jennische. 1988. IGF-I immunoreactivity is expressed by regenerating renal tubule cells after ischaemic injury in the rat. Acta Physiol. Scand. 132:453-457.

29. Matejka, G., and E. Jennische. 1992. IGF-I and IGF-I mRNA expression in the postischemic regenerating rat kidney. Kidney Int. 42:1113-1123.

30. Feinstein, E., M. Blumenkrantz, M. Healy, A. Koffler, H. Silberman, S. Massry, and J. Kopple. 1981. Clinical and metabolic responses to parenteral nutrition in acute renal failure. A controlled double-blind study. Medicine 60:124-137. 